\title{
RESEARCH PAPER \\ Vegetation survival and condition in public green spaces after their establishment: Evidence from a semi-arid metropolis.
}

\author{
Ursula Steinfort ${ }^{1}$, Américo Contreras ${ }^{2}$, Francisco Albornoz ${ }^{1}$, Sonia Reyes- \\ Paecke ${ }^{1,3}$, and Paola Guilleminot ${ }^{1}$ \\ 'Pontificia Universidad Católica de Chile, Facultad de Agronomía e Ingeniería Forestal. Vicuña Mackenna \\ 4860, Macul, Santiago, Chile. \\ ${ }^{2}$ Universidad de Chile, Facultad de Ciencias Agronómicas. Santa Rosa 11315, La Pintana, Santiago, Chile. \\ ${ }^{3}$ Center for Sustainable Urban Development (CEDEUS). El Comendador 1916, Providencia, Santiago, Chile
}

\begin{abstract}
U. Steinfort, A. Contreras, F. Albornoz, S. Reyes-Paecke, and P. Guilleminot. 2020. Vegetation survival and condition in public green spaces after their establishment: Evidence from a semi-arid metropolis. Int. J. Agric. Nat. Resour. 90-104. Urban vegetation is generally exposed to adverse environmental conditions, such as high temperatures, compacted soils, low fertility, and a high pollutant concentration. The influence of biophysical and social factors on the survival and condition of trees and nontrees was analyzed using a census of plants in 37 green spaces of the Metropolitan Region of Santiago de Chile (MRS) several years after their establishment. The tree survival rate was higher (77\%) than that of other species $(24 \%)$. Survival was primarily explained by municipality management and species selection, but the relevance of these factors differed between trees and nontrees. Species with low water requirements outperformed species that were more sensitive to water stress. A high mechanical damage rate was observed, with $91 \%$ of trees showing severe or medium damage. Soil quality was better than expected, with a bulk density less than $1.0 \mathrm{~g} \mathrm{~m}^{-3}$ and moderate and high levels of $\mathrm{P}$, and only $8 \%$ of sites had low $\mathrm{K}$ levels. The $\mathrm{N}$ content was highly variable, but most of the sites had levels greater than $20 \mathrm{mg} \mathrm{kg}^{-1}$, which indicates a trend of accumulation that is consistent with urban soils. More in-depth studies are required to establish the factors that explain plant survival in public spaces of the MRS, and irrigation monitoring is especially needed.
\end{abstract}

Keywords: Green spaces management, green spaces quality, ornamental gardening, urban soils, urban vegetation.

\section{Introduction}

Vegetation plays a fundamental role in the structuring of urban green spaces. Urban vegetation is the main provider of ecosystem services in cities via regulating the microclimate, sequestering and

Received Nov 29, 2018. Accepted Jul 27, 2020.

Corresponding author: sonia.reyes@uc.cl storing $\mathrm{CO}_{2}$, and encouraging social interaction and physical activity that improves the psychological well-being of the community (Annerstedt et al., 2012; Gillner et al., 2015; Mullaney, Lucke \& Trueman, 2015).

Understanding the quality of urban vegetation based plant survival and condition after their establishment is relevant to improve their long 
term provision of ecosystem services and aid local planners in providing sustainable urban green space designs. A range of biophysical and social factors interacting in a complex fashion underlie vegetation survival and condition (Conway \& Urbani, 2007). From a biophysical standpoint, low survival occurs when there is a mismatch between the ecophysiology of the species and its location, such as air temperature or soil characteristics (Sand et al., 2018). Urban vegetation is generally exposed to higher temperatures due to the heat island effect, the characteristics of construction materials, and air pollutants, which affect growth and survival (Vogt et al., 2017). Unlike their natural counterparts, urban soils impose limitations for vegetation growth and survival because these soils are generally compacted and covered with impervious materials that disrupt nutrient cycling and restrict water and air movement (Beatty \& Heckman, 1981; Pouyat et al., 2007; Sand et al., 2018). These characteristics translate into a low supply of essential nutrients, such as nitrogen and phosphorous, which makes the environment stressful and impacts the survival and condition of the existing vegetation (Pouyat et al., 2007).

Social factors bound to a specific location also play a role in vegetation survival and condition (Beatty \& Heckman, 1981; Conway \& Urbani, 2007). Conway \& Urbani (2007) discussed a link between the condition of existing vegetation and the socioeconomic characteristics of the neighborhood inhabitants, including household income, population density and municipal policies. The use of green spaces depends on the space quality, which is defined by the presence and condition of vegetation (Gidlow, Ellis \& Bostock, 2012). Mechanical damage affects the vegetation condition and its long-term survival, including vandalism, environmental conditions, such as strong winds or hail, and poor maintenance practices (Beatty \& Heckman, 1981; Mullaney et al., 2015). Therefore, the role of municipal policies and their resource allocation to maintenance practices, such as the fertilization or irrigation of each green space, determine the overall qual- ity of the vegetation (Beatty \& Heckman, 1981; Gilman, Black \& Dehgan, 1998; Bijoor et al., 2012). Mechanical damage associated with poor pruning practices (Badrulhisham \& Othman, 2016) or the inadequate use of lawn equipment (Morgenroth, Santos \& Cadwallader, 2015) also limit the growth, survival and the potential ecosystem services of urban trees.

Small-sized species, which are defined by their growth habits, such as shrubs, climbers, herbaceous perennials and graminoids, are essential to integrate landscape designs in green spaces and provide structure, texture, variety and aesthetic value while preventing erosion (Amoroso et al., 2010) and fostering the presence of fauna (Paker et al., 2014). A number of studies showed the importance of small-sized plants in urban green spaces because they provide a habitat for insects, birds and mammals (Matteson \& Langellotto, 2010; Matthies et al., 2017), contribute to the maintenance of soil permeability and humidity and increase the aesthetic value of the space by making the spaces more attractive to users (Matteson \& Langellotto, 2010). However, previous studies primarily focused on the role, survival and condition of urban trees, especially at the street level after their establishment, without considering the importance of smaller plants (Gilman et al., 1998; Jack-Scott et al., 2013; Ko et al., 2015; Koeser et al., 2014; Lu et al., 2010; Mullaney, Luecke \& Trueman, 2015; Nowak, Kuroda \& Crane, 2004; Roman \& Scatena, 2011; Roman, Battles \& McBride, 2013; Roman, Battles \& McBride, 2014). Koeser et al. (2014) reported tree survival rates in the range of 0.5 to $100 \%$, although rates over $60 \%$ are commonly achieved. Despite the importance of shrubs, climbers, herbaceous perennials and graminoids, to the best of our knowledge, no studies recorded their survival or condition after their establishment in green spaces.

The present study addressed this gap in knowledge by comparing the role of biophysical and social factors in the survival and condition of trees and smaller species, such as shrubs, climbers, 
herbaceous perennials and graminoids (nontrees), after their establishment. Vegetation survival and condition in 37 green spaces of 12 municipalities in the semi-arid Metropolitan Region of Santiago de Chile (MRS) were analyzed based on their relationship to several variables, such as species selection, air temperature, relative humidity, soil chemical and physical characteristics, mechanical damage, green space location within each municipality, amount and the socioeconomic level of the population near the green spaces. We hypothesized that tree survival and condition in green spaces were not similar to shrubs, climbers, herbaceous perennials and graminoids (nontrees) and that combinations of more than one biophysical and social factor would explain these differences. The present study analyzed air temperature, relative humidity, soil chemical and physical characteristics, green space location within each municipality, the number of inhabitants living at a maximum distance of 500 meters from the green space and their socioeconomic level. This information will contribute to the understanding of vegetation survival and condition after plant establishment and provide sound information for future decision-making to aid in the design of sustainable green spaces over time.

\section{Materials and methods}

\section{Study site}

We assessed plant survival and condition in public green spaces of the MRS, which is the administrative and economic center of Chile (Fig. 1). It has a population of 7.1 million inhabitants, concentrating $40 \%$ of the country's population, and it is divided into six provinces and 52 municipalities (Fig. 1). It is located at an average of 567 m.a.s.l. between the Coastal and the Andean mountain ranges, at latitudes $32^{\circ} 55^{\prime}$ to $34^{\circ} 19^{\prime} \mathrm{S}$ and longitudes $60^{\circ} 47^{\prime}$ to $71^{\circ} 42^{\prime} \mathrm{W}$. According to the KöppenGeiger climate classification, the area is defined as Mediterranean (csb) (Kottek et al., 2006), with an average annual rainfall of $300 \mathrm{~mm}$ distributed in the winter months, hot summers and a dry season that lasts for seven to eight months.

\section{Green spaces and plant species}

Thirty-seven green spaces established between 2012 and 2015, located in 13 municipalities of the MRS were selected (Fig. 2) from a database provided by a non-governmental organization (Fundación Mi Parque). Green space surface ranged between 301 and 11,904 square meters, with a median of 1383.7 square meters. These green spaces had at least 10 individual trees and 12 established shrubs, climbers, herbaceous perennials or graminoids. The local residents participated in the design of the spaces, and nongovernmental organization (NGO) volunteers planted the vegetation. Residents on a predefined list from the NGO selected the plant species, which included frequent ornamental species in public spaces in Santiago. Planting was performed simultaneously in each green space, and there was a record of the species that were initially planted. The age of individual plants varied between 2 and 5 years. Although the NGO indicated that all green spaces were regularly irrigated, there were no records of the water amounts used for irrigation or the irrigation frequency during the analyzed period. A total of 16 species of trees, 10 shrubs, six climbers and six herbaceous perennials and graminoids were established in the green spaces. Choices of trees, shrubs, climbers, herbaceous perennials and graminoids were made based on growth habits and morphological features, such as the presence (trees, shrubs and climbers) or absence (herbaceous perennials and graminoids) of secondary growth and erect (trees and shrubs) or decumbent plants (climbers) according to the USDA (2018) classification (Table 1).

\section{Soil and weather data}

We collected three composite soil samples at each green space. Samples were taken at a $25-\mathrm{cm}$ depth, 
Table 1. Species, family, center of origin, growth habit and number of individuals established between 2012 and 2015 in the 37 green spaces

\begin{tabular}{|c|c|c|c|c|}
\hline Species & Family & Center of origin & Growth habit & $\mathrm{n}$ \\
\hline Bougainvillea spectabilis & Nyctaginaceae & Brazil & Climber & 98 \\
\hline Hedera helix & Araliaceae & Europe and Western Asia & Climber & 70 \\
\hline Jasminum $s p$ & Oleaceae & Asia & Climber & 699 \\
\hline Lantana sellowiana & Verbenaceae & South America & Climber & 85 \\
\hline Lonicera $s p$ & Caprifoliaceae & Asia & Climber & 197 \\
\hline Wisteria sinensis & Fabaceae & China & Climber & 4 \\
\hline Cortaderia selloana & Poaceae & South America & Graminoid & 402 \\
\hline Agave americana & Agavaceae & North America & Herbaceous perennial & 106 \\
\hline Gaura lindheimeri & Onagraceae & North America & Herbaceous perennial & 715 \\
\hline Kniphofia sp & Asphodelaceae & South Africa & Herbaceous perennial & 218 \\
\hline Puya chilensis & Bromeliaceae & Chile & Herbaceous perennial & 258 \\
\hline Sisyrinchium striatum & Iridaceae & South America & Herbaceous perennial & 282 \\
\hline Hebe speciosa & Plantaginaceae & New Zealand & Shrub & 238 \\
\hline Lavandula officinalis & Lamiaceae & Europe, Africa and Asia & Shrub & 1976 \\
\hline Ligustrum sinense & Oleaceae & Asia & Shrub & 75 \\
\hline Myoporum parvifolium & Scrophulariacea & Australia & Shrub & 294 \\
\hline Nerium oleander & Apocynaceae & Europe, Africa and Asia & Shrub & 147 \\
\hline Plumbago auriculata & Plumbaginaceae & South Africa & Shrub & 54 \\
\hline Rosa $s p$ & Rosaceae & Asia & Shrub & 1347 \\
\hline Rosmarinus officinalis & Lamiaceae & Europe & Shrub & 287 \\
\hline Santolina chamaecyparissus & Asteraceae & Europe and Africa & Shrub & 520 \\
\hline Westringia $s p$ & Lamiaceae & Australia & Shrub & 272 \\
\hline Brachychiton populneus & Malvaceae & Australia & Tree & 60 \\
\hline Catalpa bignonioides & Bignoniaceae & United States & Tree & 14 \\
\hline Cercis siliquastrum & Fabaceae & Europe and Western Asia & Tree & 23 \\
\hline Elaeagnus angustifolia & Elaeagnaceae & Europe and Asia & Tree & 215 \\
\hline Jacaranda mimosifolia & Bignoniaceae & South America & Tree & 23 \\
\hline Liquidambar styraciflua & Altingiaceae & North America & Tree & 16 \\
\hline Liriodendron tulipifera & Magnoliaceae & North America & Tree & 3 \\
\hline Maytenus boaria & Celastraceae & South America & Tree & 19 \\
\hline Melia azedarach & Meliaceae & Asia and Oceania & Tree & 114 \\
\hline Parkinsonia aculeata & Fabaceae & $\begin{array}{c}\text { North, Central and South } \\
\text { America }\end{array}$ & Tree & 199 \\
\hline Prunus cerasifera & Rosaceae & Europe and Asia & Tree & 2 \\
\hline Prunus sp. & Rosaceae & Europe and Asia & Tree & 8 \\
\hline Quillaja saponaria & Rosaceae & Chile & Tree & 69 \\
\hline Robinia pseudoacacia & Fabaceae & North America & Tree & 8 \\
\hline Schinus molle & Anacardiaceae & South America & Tree & 188 \\
\hline Thuja sp. & Cupressaceae & North America & Tree & 1 \\
\hline
\end{tabular}




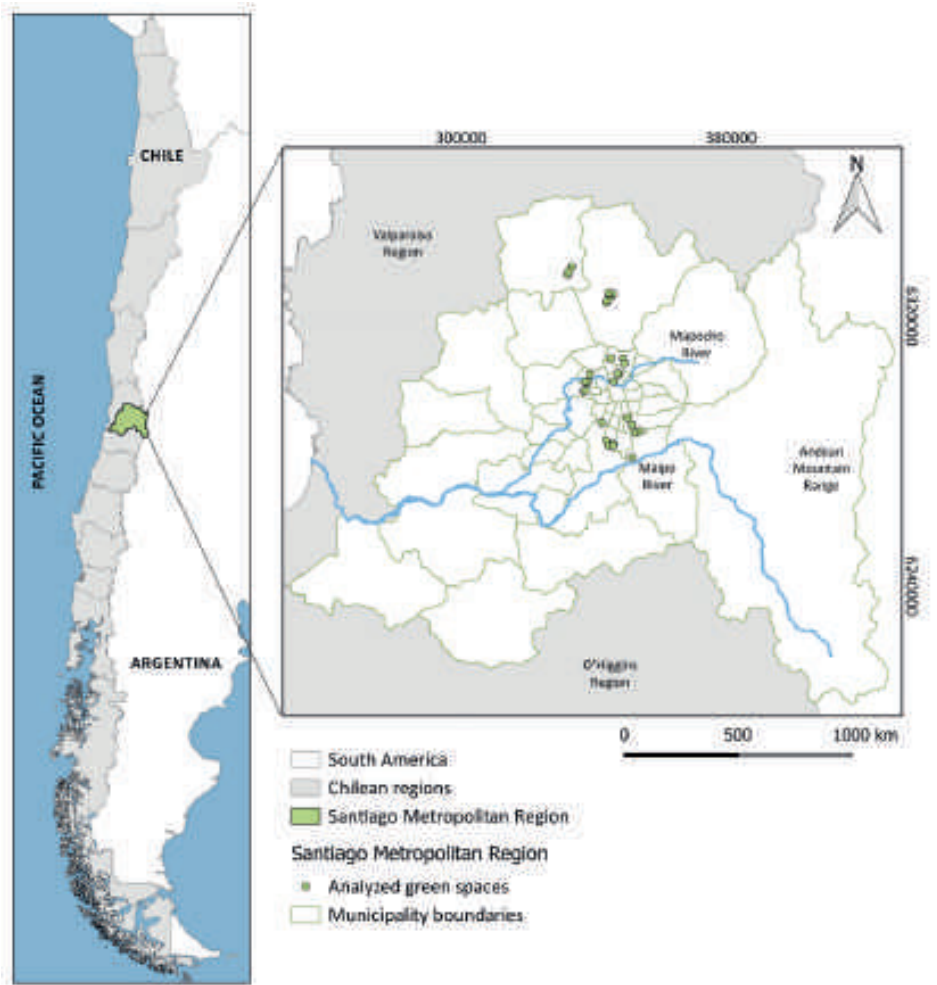

Figure 1. Study site, Santiago Metropolitan Region.

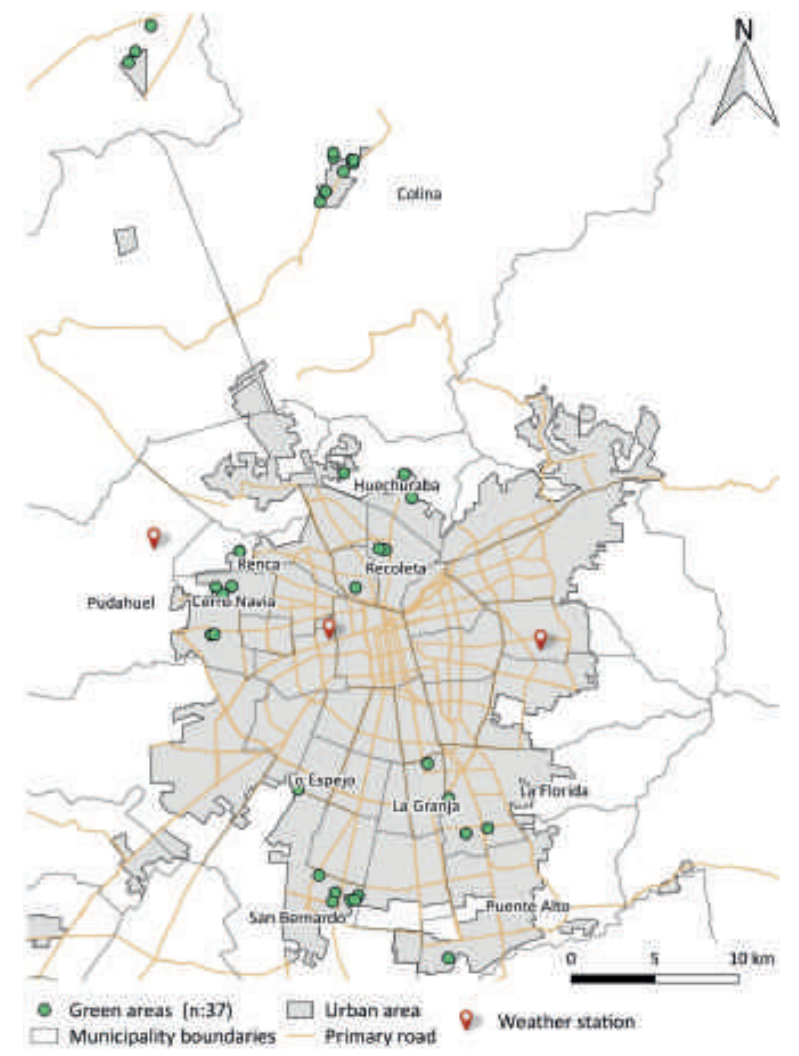

Figure 2. Map showing administrative divisions and the locations of the sites and weather stations. 
two meters from any tree and where shrubs were present. Following the methodology described by Sadzawka et al. (2006), we determined the $\mathrm{pH}$, electrical conductivity (EC), organic matter and nitrogen $(\mathrm{N})$, phosphorus $(\mathrm{P})$ and potassium $(\mathrm{K})$ contents in each sample. Bulk density was measured in eight of the green spaces, including four spaces with a high (75-100\%) tree survival rate and four spaces with low rates (less than 75\%). The green spaces selected for bulk density analysis had a surface area of at least $1000 \mathrm{~m}^{2}$ (Table 2). Four samples were taken at each site using a cylinder at a depth of 0 to $10 \mathrm{~cm}$ and one meter away from any tree, as described by Close, Nguyen \& Kielbaso (1996). The samples were dried in an oven at $105^{\circ} \mathrm{C}$ for

Table 2. Soil $\mathrm{pH}$, electrical conductivity $(\mathrm{EC})$, organic matter $(\mathrm{OM})$, nitrogen $(\mathrm{N})$, phosphorous $(\mathrm{P})$ and potassium $(\mathrm{K})$ content at the study sites.

\begin{tabular}{|c|c|c|c|c|c|c|}
\hline Study site & $\mathrm{pH}$ & $\begin{array}{c}\mathrm{EC} \\
\left(\mathrm{mS} \mathrm{cm}^{-1}\right)\end{array}$ & $\begin{array}{l}\mathrm{OM} \\
(\%)\end{array}$ & $\begin{array}{c}\mathrm{N} \\
\left(\mathrm{mg} \mathrm{kg}^{-1}\right)\end{array}$ & $\begin{array}{c}\mathrm{P} \\
\left(\mathrm{mg} \mathrm{kg}^{-1}\right)\end{array}$ & $\begin{array}{c}\mathrm{K} \\
\left(\mathrm{mg} \mathrm{kg}^{-1}\right)\end{array}$ \\
\hline Plaza La Africana $^{+}$ & 7.6 & 1.42 & 4.97 & 107 & 266 & 956 \\
\hline Plaza Libertad ${ }^{*+}$ & 7.5 & 1.19 & 1.43 & 38 & 81 & 322 \\
\hline Plaza M. C. Arredondo ${ }^{+}$ & 7.8 & 2.01 & 1.30 & 179 & 30 & 284 \\
\hline Plaza La Unión ${ }^{+}$ & 7.9 & 0.33 & 1.56 & 20 & 66 & 323 \\
\hline Plaza Ina Ina ${ }^{+}$ & 7.3 & 0.97 & 2.56 & 114 & 56 & 336 \\
\hline Plaza Nuestro Parque & 7.5 & 5.50 & 1.13 & 1321 & 40 & 219 \\
\hline Plaza Sonrisas de $\mathrm{Niño}^{+}$ & 8.0 & 0.30 & 1.55 & 55 & 20 & 272 \\
\hline Mi Parque Fénix ${ }^{+}$ & 8.0 & 0.29 & 2.05 & 16 & 18 & 306 \\
\hline Plaza El Encuentro ${ }^{+}$ & 8.0 & 0.59 & 2.62 & 34 & 50 & 241 \\
\hline Plaza Villa Esperanza ${ }^{+}$ & 7.8 & 0.36 & 1.43 & 22 & 57 & 105 \\
\hline Plaza Estrellita Fuste ${ }^{*_{+}}$ & 7.5 & 1.53 & 3.84 & 29 & 70 & 539 \\
\hline Plaza Los $90^{+}$ & 7.7 & 0.92 & 1.89 & 19 & 77 & 199 \\
\hline Plaza Nueva Vida*+ & 7.6 & 0.65 & 3.52 & 9 & 24 & 356 \\
\hline Parque Las Alamedas* & 7.7 & 0.94 & 1.56 & 6 & 17 & 160 \\
\hline Plaza Unión San Pedro*+ & 7.4 & 0.54 & 3.90 & 24 & 36 & 288 \\
\hline Plaza Renacer $^{+}$ & 7.0 & 0.92 & 5.46 & 157 & 168 & 574 \\
\hline Plaza Los Eucaliptus $^{+}$ & 7.7 & 3.46 & 1.34 & 62 & 28 & 323 \\
\hline Plaza Violeta Parra ${ }^{+}$ & 7.3 & 0.69 & 5.04 & 54 & 84 & 143 \\
\hline Plaza Massu el cartero $^{+}$ & 7.6 & 0.87 & 3.87 & 33 & 31 & 363 \\
\hline Plaza Renacer & 7.4 & 2.80 & 4.28 & 55 & 79 & 253 \\
\hline Plaza Finlandia $^{+}$ & 8.0 & 0.54 & 0.64 & 23 & 17 & 402 \\
\hline Plaza Mi Barrio $^{+}$ & 7.7 & 1.16 & 1.15 & 55 & 44 & 160 \\
\hline Plaza Primavera $^{+}$ & 7.6 & 0.81 & 3.24 & 39 & 35 & 299 \\
\hline Plaza Alfonso Ortega & 7.7 & 0.94 & 1.85 & 5 & 12 & 180 \\
\hline Plaza José María Caro & 7.6 & 1.34 & 2.19 & 7 & 26 & 203 \\
\hline Plaza San Rafael ${ }^{*}$ & 7.4 & 1.50 & 4.48 & 86 & 61 & 324 \\
\hline Plaza Peynantun ${ }^{+}$ & 7.8 & 0.59 & 2.43 & 44 & 44 & 468 \\
\hline Parque Confraternidad & 7.8 & 2.51 & 1.54 & 10 & 20 & 247 \\
\hline Parque de Santa Marta ${ }^{*+}$ & 8.1 & 0.22 & 1.19 & 14 & 17 & 120 \\
\hline Plaza el Alarife ${ }^{+}$ & 8.0 & 0.19 & 1.27 & 17 & 65 & 195 \\
\hline Plaza La Esperanza $^{+}$ & 8.1 & 0.28 & 1.63 & 13 & 30 & 172 \\
\hline Plaza Monseñor Fresno ${ }^{+}$ & 7.8 & 0.54 & 2.36 & 66 & 38 & 256 \\
\hline Plaza San Matías ${ }^{*+}$ & 7.9 & 0.39 & 1.98 & 27 & 32 & 171 \\
\hline Plaza Sandro Escalona & 7.5 & 2.83 & 1.12 & 14 & 21 & 194 \\
\hline Parque H. Familiares & 7.9 & 0.43 & 2.63 & 49 & 33 & 566 \\
\hline Plaza Delfín Oyanedel & 8.0 & 0.38 & 1.26 & 37 & 23 & 427 \\
\hline Plaza Rinconcito Verde & 7.8 & 0.60 & 2.22 & 32 & 89 & 593 \\
\hline Mean $\pm \mathrm{SE}$ & $7.7 \pm 0.3$ & $1.1 \pm 1.1$ & $2.4 \pm 1.3$ & $78.2 \pm 213.8$ & $51.5 \pm 47.2$ & $311.9 \pm 168.4$ \\
\hline
\end{tabular}

*Sites selected for soil compaction analysis. + Sites with available socioeconomic data 
24 hours, sieved and weighed. Bulk density was calculated as the ratio between the dry weight $(\mathrm{g})$ and the volume of the cylinder $\left(\mathrm{cm}^{3}\right)$.

Air temperature and relative humidity records were obtained from three meteorological stations in the MRS (Dirección Meteorológica de Chile, 2016) (Fig. 2). We calculated the average, minimum and maximum temperatures and the average relative humidity (RH) from the establishment of the green space until December 2015.

\section{Socioeconomic data}

Socioeconomic data of the population living at a maximum distance of 500 meters from 26 green space sites (Table 2) were retrieved from census data. Based on the income, education level and property ownership, households where categorized into one of the following socio-economic groups: upper and upper-middle class (ABC1), middle class (C2), lower-middle class (C3), poor (D), or extremely poor (E) (Adimark, 2017).

\section{Measurements}

We recorded the number of individual plants in each green space in December 2015, during the active growing season. No dead plants were replaced between the establishment and the census to ensure reliable data collection. Survival per species after establishment was calculated following the methodology proposed by Koeser et al. (2014). The condition of each individual plant was assessed based on the presence or absence of mechanical damage. Three levels of mechanical damage were assigned to each individual: minor (no damage or just damaged leaves), moderate (plants exhibited broken branches or cuts through the phloem that were unlikely to cause death) or severe (damage present over most of the plant that was likely to cause death). Cuts through the phloem and xylem caused by maintenance equipment were also considered mechanical damage (Fig. 3).

\section{Data analysis}

Plant survival data were analyzed using a generalized linear mixed model (GLMM), a binomial distribution and a logit link function following Bolker et al. (2009). Original data were divided between trees and nontree species, which included shrubs, climbers, herbaceous perennials and graminoids. The variable number of months after establishment and survival evaluations were considered fixed effects, and municipality manage-
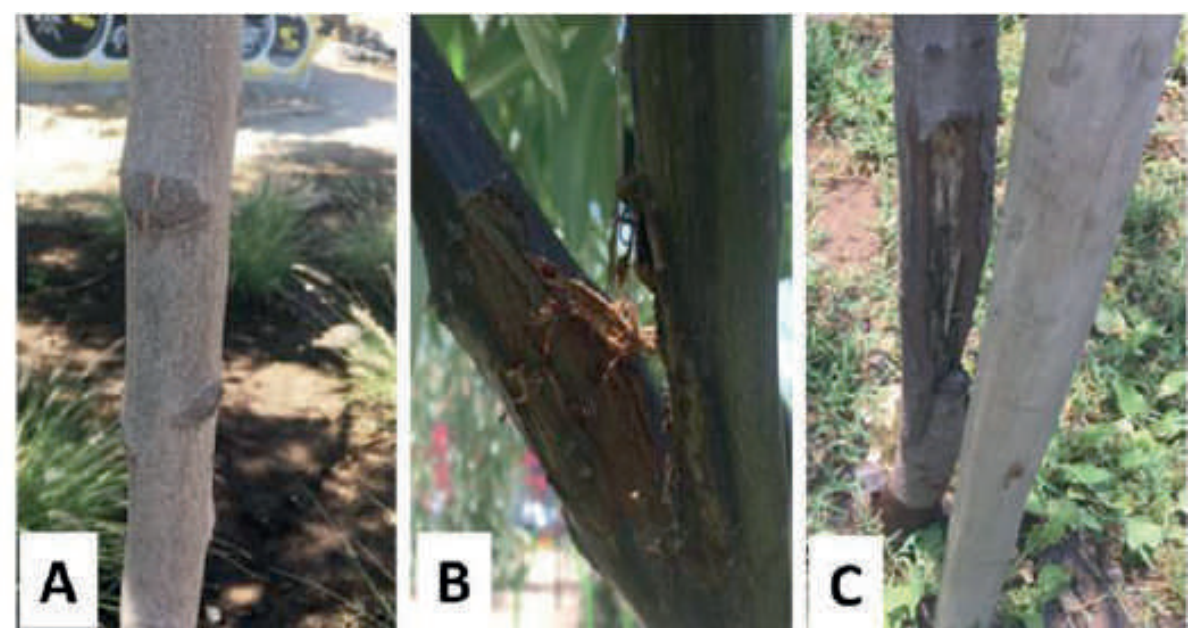

Figure 3. Qualitative scale for mechanical damage. (L) minor, (M) moderate and (H) severe mechanical damage. 
ment, green space, and species were considered nested random effects. We followed the rule that any variable treated as random within the model had more than five categorical levels (Bolker et al., 2009) A 0.05 significance level was used to make inferences about the number of months parameter. Correlation structures between the degree of mechanical damage (minor, moderate or severe), socioeconomic groups (ABC1, C2, C3, $\mathrm{D}, \mathrm{E})$ and number of people living around the sites were analyzed using principal component analysis and presented in biplot graphics, as suggested by Gabriel (1971). To avoid spurious correlations, compositional data (mechanical damage and socioeconomic groups) were transformed using a centered log-ratio transformation (Van den Boogaart \& Tolosana-Delgado, 2013).

Generalized linear mixed models were estimated using the Ime4 package (Bates et al., 2015), and biplots were made using the ade4 package (Dray \& Dufour, 2007). All analyses used R programming language (R Core Team, 2011). Soil compaction data were analyzed using ANOVA, and mean separation was performed using the least significant difference (LSD) test when necessary, using InfoStat software (Di Rienzo et al., 2014). A principal component analysis was performed to identify the variables or combination of variables that best explained the observed survival rates for trees and nontrees. Soil $\mathrm{pH}, \mathrm{EC}$, organic matter content, $\mathrm{N}$ content, $\mathrm{P}$ content, $\mathrm{K}$ content, and bulk soil density were considered.

\section{Results}

A total of 962 trees and 8,344 nontrees (shrubs, climbers, herbaceous perennials and graminoids) were established in the 37 green spaces, with survival rates of $77 \%$ (736 individuals) and $24 \%$ (2,031 individuals), respectively. Individual plants that were not found were presumed dead. Survival tended to decline with time after establishment, but the number of months after the establishment was nonsignificant in the models for trees $(p=0.7851)$ and nontrees $(p=0.355)$. Municipality management explained $66.7 \%$ of total tree survival variability, and green space location within the municipality explained only $6 \%$. Species selection accounted for $27.3 \%$ of total tree survival variability. Tree survival ranged from 50 to $100 \%$ among municipalities and 47 to $100 \%$ among green spaces (Figs. 4 and 5). Similarly, the variability in nontree survival was explained $79.9 \%$ by the municipality, $10.5 \%$

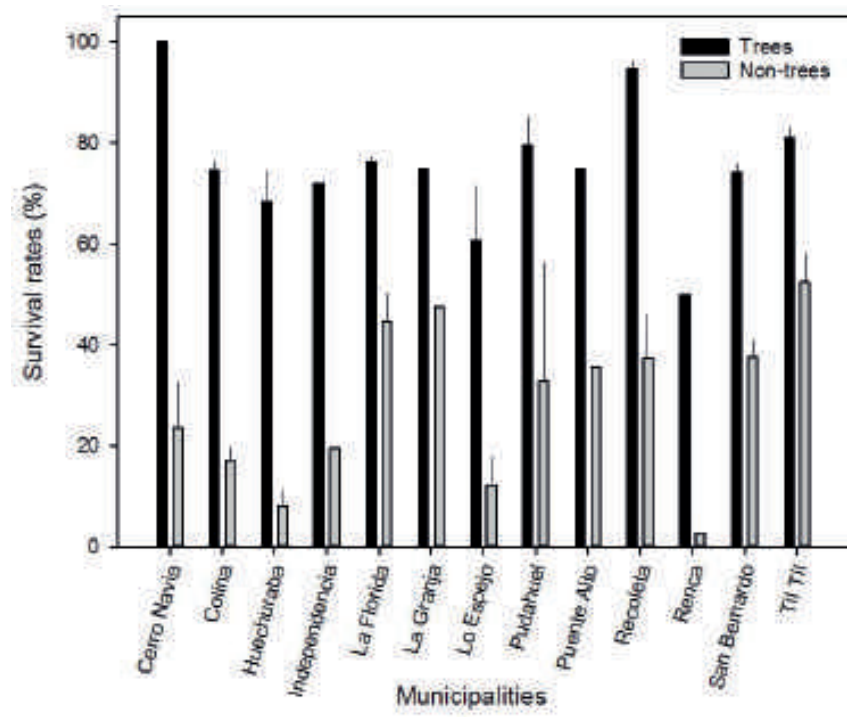

Figure 4. Survival rate of trees, shrubs, climbers, graminoids and herbaceous perennials (nontrees) per municipality. 


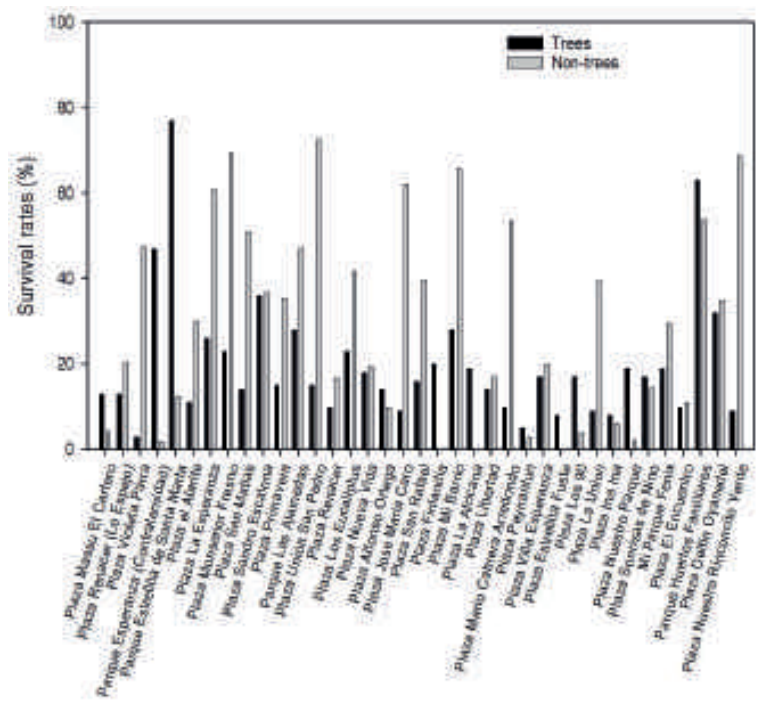

Figure 5. Survival rate of trees, shrubs, climbers, graminoids and herbaceous perennials (nontree plants) per study site

by the green space location and $9.6 \%$ by species selection. However, nontree survival varied among municipalities and green spaces from 3 to $52 \%$ and 2 to $72 \%$, respectively (Figs. 4 and 5).

The classification of mechanical damage level in trees showed that $38 \%$ of the individuals had no damage, $51 \%$ had moderate, and $11 \%$ had severe damage (Fig. 6). Although fewer nontree plants survived, the plants were in better condition than trees, with $67 \%$ of plants showing no mechanical damage, 24\% with moderate level and 9\% with severe damage. No relationships between mechanical damage incidence and the number of homes classified in any of the socioeconomic groups or with the number of inhabitants around the site were found (Fig. 7).

Soil EC and nutrient content were highly variable between green spaces (Table 2). However, no relationship was found between tree survival and soil $\mathrm{pH}(\mathrm{p}=0.5462), \mathrm{EC}(\mathrm{p}=0.6157)$, organic matter content $(p=0.3361), N$ content $(p=0.9222)$, $P$ content $(\mathrm{p}=0.4445)$ or $\mathrm{K}$ content $(\mathrm{p}=0.9505)$. Similar results were found for nontree survival. Bulk soil density ranged from 0.82 to $1.09 \mathrm{~g} \mathrm{~cm}^{-3}$, but no significant relationship was found with tree $\operatorname{survival}(\mathrm{p}=0.1693)$ or nontree survival $(\mathrm{p}=0.3825)$.
Little variations between green spaces were found for average minimum temperature $\left(8.8^{\circ} \mathrm{C} \pm 0.4\right)$, mean temperature $\left(15.5^{\circ} \mathrm{C} \pm 1.1\right)$, maximum temperature $\left(23.3^{\circ} \mathrm{C} \pm 0.6\right)$ and average relative humidity $(60.2 \% \pm 1.1)$. Tree survival was not related to minimum, mean and maximum temperatures or relative humidity, with $\mathrm{p}$ values of $0.2522,0.7627,0.2829$ and 0.7375 , respectively. Similarly, no relationship between nontree survival and minimum, mean and maximum temperatures or RH were found, with $p$ values of $0.1349,0.7348$, 0.1413 and 0.2732 , respectively.

A significant relationship $(\mathrm{p}=0.001)$ between the number of households and the number of inhabitants was found. Most inhabitants were in the lower socioeconomic groups, but the number of inhabitants per socioeconomic group did not explain the survival or mechanical damage to trees or nontrees (Fig. 7).

As mentioned above, species selection explained $27.3 \%$ of the variability in tree survival (Fig. 7 ). The species reaching greater than $75 \%$ survival were Brachychiton populneus, Eleagnus angustifolia, Jacaranda mimosifolia, Maytenus boaria, Melia azedarach and Parkinsonia aculeata (Table 1, Fig. 8A). Maytenus boaria, Quillaja saponaria 

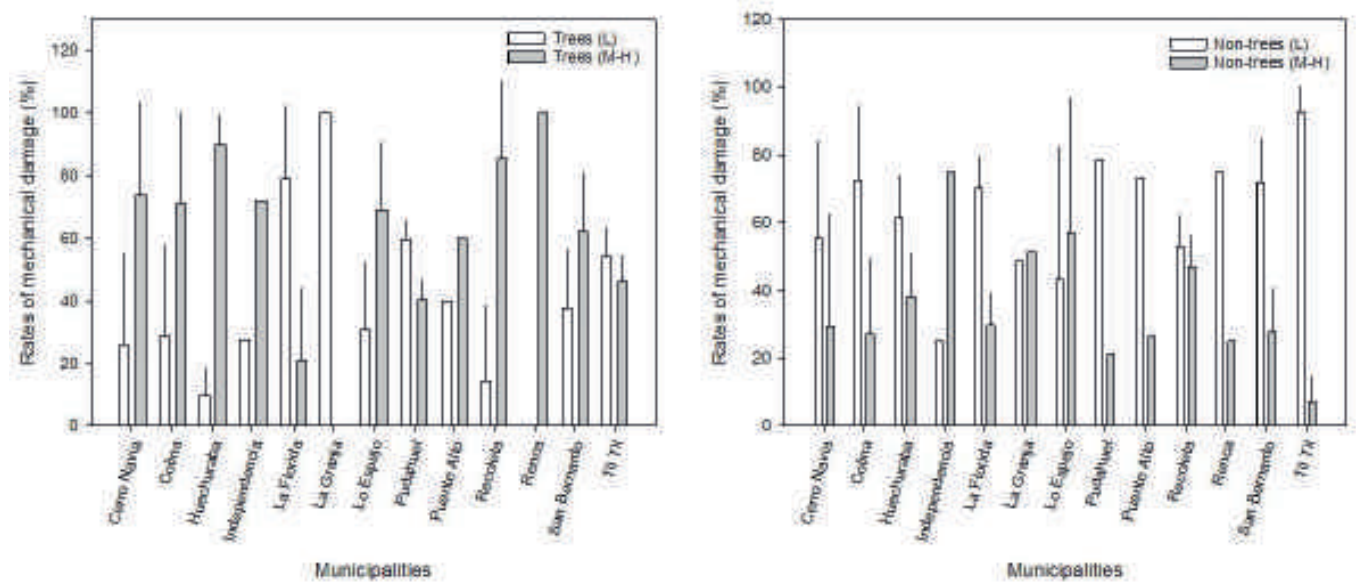

Figure 6. Rates of minor $(\mathrm{L})$, moderate $(\mathrm{M})$ and severe $(\mathrm{H})$ mechanical damage to $(\mathrm{A})$ trees and $(\mathrm{B})$ shrubs, climbers, graminoids and herbaceous perennials (nontrees) per municipality
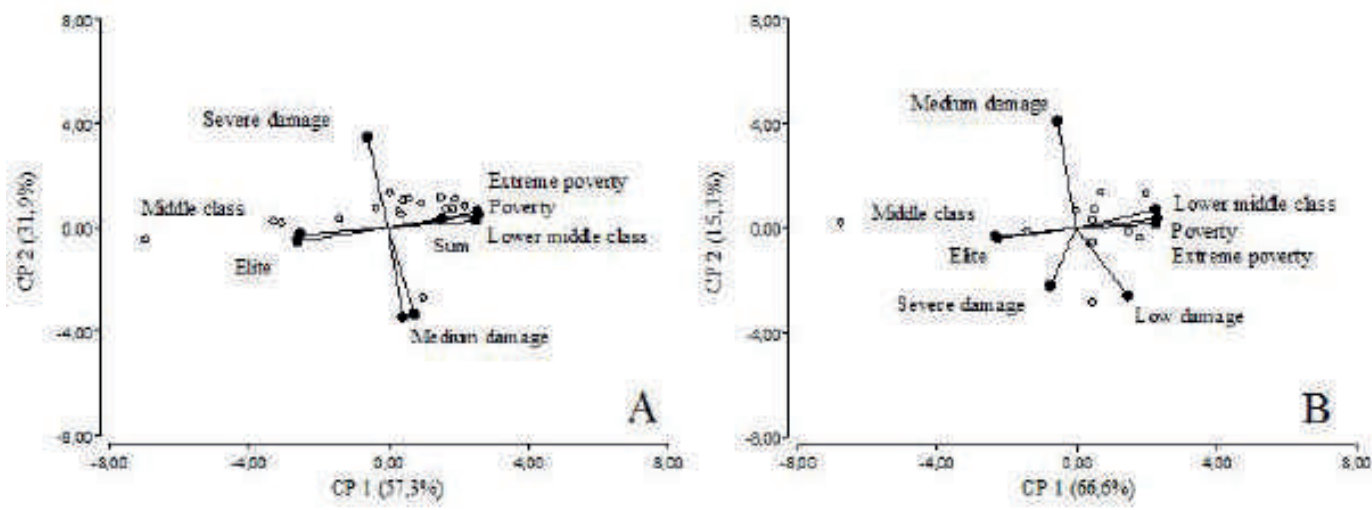

Figure 7. Principal component analyses of mechanical damage (minor, moderate, severe) and number of inhabitants per socioeconomic group. (A) trees, and (B) nontrees, namely, shrubs, climbers, graminoids, and herbaceous perennials

and Schinus molle were the only native species of the 16 species planted. Species selection was less important in explaining variability in the survival of nontree species (only 9.6\%). Only Agave americana $(\mathrm{n}=106)$ and Wisteria sinensis $(\mathrm{n}=4)$ reached $100 \%$ survival (Table 1, Fig. 8B). Among the nontree group, only Sisyrinchium striatum, Cortadeira selloana and Puya chilensis were native species.

\section{Discussion}

The present study found that tree survival rates were largely higher (77\%), which is consistent with previous studies that reported values between $74 \%$ and 96\% (Jack-Scott et al., 2013; Lu et al., 2010; Roman \& Scatena, 2011; Roman et al., 2013). In contrast, nontrees had lower survival rates $(24 \%)$, but comparison data from similar studies are not available. The results showed that survival was related to municipality management and species selection, but the relevance of these factors in explaining survival changed between trees and the group of shrubs, climbers, perennials and graminoids (nontrees).

Municipality management was by far the most important variable that explained the survival 

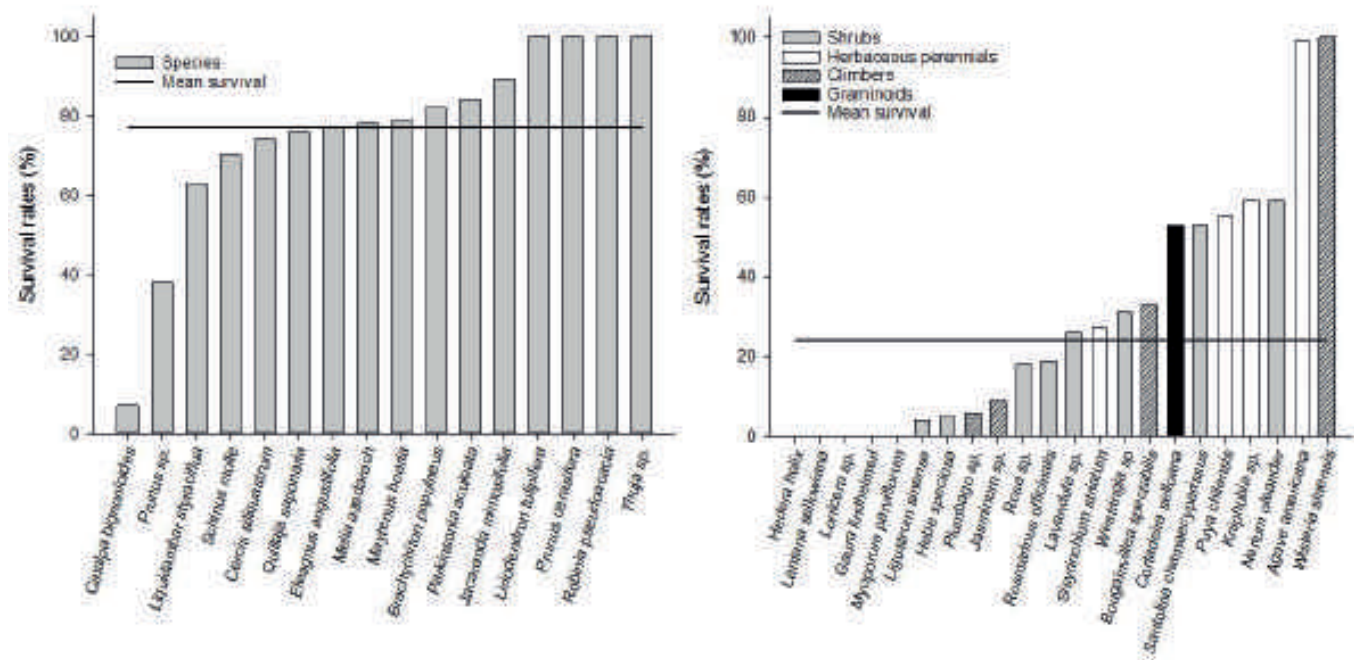

Figure 8. Survival rates of (A) trees and (B) shrubs, climbers, graminoids, and herbaceous perennials (nontrees) per species

of trees and nontrees, which is consistent with other studies that reported that the quality of maintenance was an important factor of urban vegetation survival (Beatty \& Heckman, 1981; Gilman et al., 1998). There were differences of up to six times in the budget allocated to green space maintenance by municipalities in MRS, with the highest budgets in the higher income municipalities (Escobedo et al., 2006). Therefore, green spaces has a greater vegetation cover, higher plant diversity and plants in better condition in the municipalities with higher income (De la Barrera, Reyes-Paecke \& Banzhaf, 2016; Hernández \& Villaseñor, 2018). Although the study covered low and middle income municipalities in the context of the metropolitan region, we found differences in vegetation survival and condition that were associated with the municipal budget allocated.

The main limitation of the present study is the lack of a record of irrigation applied in the analyzed green spaces. This lack prevents establishing relationships between irrigation (e.g., quantity and frequency) and plant survival, and it prevented the estimation of irrigation requirements for vegetation survival under the MRS environmental and climatic conditions. Therefore, specific recom- mendations on irrigation cannot be provided based on the results of the study.

However, the study obtained interesting results on soil quality. The bulk density was quite low, with all values below $1.0 \mathrm{~g} \mathrm{~cm}^{3}$, which is positive for plant development because it does not impose restrictions on the movement of water through the soil profile or root growth. Therefore, there was no correlation between bulk soil density and tree survival in the sampled green spaces. This result is very positive considering that urban soils are characterized as highly compacted. For soil nutrient content, all of the samples contained moderate to high levels of $\mathrm{P}$, and only $8 \%$ of the sites had a low content of $\mathrm{K}$ using 10 and $150 \mathrm{mg} \mathrm{kg}^{-1}$ as the lower limits for $\mathrm{P}$ and $\mathrm{K}$, respectively (Horneck et al., 2011). N content varied considerably between sites, with values as low as $5 \mathrm{mg} \mathrm{kg}^{-1}$ and as high as $1,321 \mathrm{mg} \mathrm{kg}^{-1}$. A trend towards $\mathrm{N}$ accumulation was observed, and the $\mathrm{N}$ content was greater than $20 \mathrm{mg} \mathrm{kg}^{-1}$ in $70 \%$ of green spaces, which is consistent with Setala et al. (2016) who concluded that urban parks promoted the accumulation of $\mathrm{N}$ in the soil regardless of plant litter removal. A more extensive study is recommended to better evaluate the soil quality in green spaces and its variability across the MRS communities. 
Species selection was more relevant in explaining the survival rates of trees than nontrees. However, trees and nontrees with low water requirements surpassed species with greater sensitivity to water stress. Similar to previous studies in MRS, our results showed a strong dominance of exotic over native species (Hernández \& Villaseñor, 2018; Figueroa et al., 2018). Figueroa et al. (2018) reported that only $16.2 \%$ of plant species in urban parks were native and showed that park area and age influenced native plant richness, but exotic plant richness was determined only by park age. The present study detected a low presence of pests and diseases (data not shown), which indicates that biotic factors were unlikely to interfere with species selection and survival, as suggested in other studies (Beatty \& Heckman, 1981; Nowak et al., 2004).

Green space location within the municipality affected survival of trees and nontrees, but it was not explained by the number of inhabitants surrounding the location or their socioeconomic characteristics. Although human behavior is an important factor in ensuring vegetation survival and condition, the present study did not investigate this aspect. According to municipal information, there is a high prevalence of vandalism, i.e., intentional or accidental damage to trees and other plants, in MRS green spaces, which led to their total or partial destruction (Reyes-Paecke et al., 2015). Vandalism could explain the high percentage $(91 \%)$ of plants with mechanical damage found, but this type of damage may also be caused by wind, rain, lawn maintenance equipment or inadequate pruning practices (Beatty \& Heckmann, 1981). Therefore, it is not possible to conclusively identify the factors affecting the integrity of the vegetation, but only to recommend to the municipalities that they take actions to reduce this high damage rate to public vegetation.

The present study is a first approach to the problem of vegetation long-term survival in public green spaces of MRS. Previous studies only recorded the composition of species and/or the vegetation cover of green spaces at a certain point in time. The results of the present study identified species with a higher survival rate in public green spaces, warned of the high rate of mechanical damage to the vegetation, and showed that the soil quality was better than expected for urban green spaces. The applied method, which consisted of a census of plants a number of years after planting, was insufficient to determine the causes of plant survival or disappearance, and we could not generate detailed indications for better management. However, this method is easy to perform and feasible for public spaces, which provides an advantage for implementation at the municipal level. Deeper studies are required to better understand the relative influence of various factors, such as the amount and frequency of irrigation, soil moisture retention capacity, pruning and cleaning practices, the frequency of vegetation remains removal, and other actions that affect the vegetation development.

\section{Resumen}

U. Steinfort, A. Contreras, F. Albornoz, S. Reyes-Paecke, y P. Guilleminot. 2020. Sobrevivencia y estado de la vegetación en áreas verdes públicas después de su establecimiento: evidencia desde una metrópolis semiárida. Int. J. Agric. Nat. Resour. 90-104. La vegetación urbana se encuentra usualmente expuesta a condiciones ambientales adversas, tales como altas temperaturas, suelos compactados y de baja fertilidad, además de una alta concentración de contaminantes. Se analizó la influencia de factores biofísicos y sociales sobre la sobrevivencia y el estado de árboles, arbustos y plantas de menor tamaño, mediante un censo de plantas en 37 áreas verdes del Área Metropolitana de Santiago de Chile (AMS) 
realizado varios años después de su establecimiento. La tasa de sobrevivencia de árboles fue mayor (77\%) que la del resto de especies (24\%). La sobrevivencia se explica principalmente por el manejo municipal y la selección de especies, pero la relevancia de estos factores difiere entre los árboles y otras plantas. Las especies con menores requerimientos hídricos sobreviven más que aquellas sensibles al estrés hídrico. Se observó una alta tasa de daño mecánico con el $91 \%$ de los árboles con daño grave o medio. La calidad del suelo fue mejor de lo esperada con una densidad aparente menor a $1.0 \mathrm{~g} \mathrm{~m}^{-3}$, niveles moderados y altos de $\mathrm{P}$, y sólo un $8 \%$ de sitios con bajo nivel de $\mathrm{K}$. El contenido $\mathrm{N}$ fue muy variable, pero la mayoría de los sitios presenta niveles mayores a $20 \mathrm{mg} \mathrm{kg}^{-1}$ lo que indica una tendencia a la acumulación consistente con suelos urbanos. Se requieren estudios más detallados para establecer los factores que explican la sobrevivencia de las plantas en espacios públicos, y especialmente se requiere un monitoreo del riego aplicado.

Palabras clave: Arbolado urbano, calidad de áreas verdes, manejo de áreas verdes, suelos urbanos, vegetación urbana.

\section{References}

Adimark (2017) Mapa socioeconomico de Chile. Retrieved from http://www.adimark.cl/medios/ estudios/Mapa_Socioeconomico_de_Chile.pdf.

Amoroso, G., Frangi, P., Piatti, R., Fini, A., \& Ferrini, $F$ (2010). Evaluation of shrubs to slope consolidation in urban landscape. Acta Horticulturae 881:241-246. https://doi.org/ 10.17660/ ActaHortic.2010.881.31

Annerstedt, M., Östergren, P.O., Björk, J., Grahn, P., Skärbäck, E., \& Währborg, P. (2012). Green qualities in the neighbourhood and mental health - results from a longitudinal cohort study in Southern Sweden. BMC Public Health 12:337. https://doi.org/10.1186/1471-2458-12-337

Badrulhisham, N., \& Othman, N. (2016). Knowledge in Tree Pruning for Sustainable Practices in Urban Setting: Improving Our Quality of Life. Procedia - Social and Behavioral Sciences 234:10-217. https://doi.org/10.1016/j.sbspro.2016.10.236

Bates, D., Mächler, M., Bolker, B., \& Walker, S. (2015). Fitting linear mixed-effects models using lme4. Journal of Statistical Software 67(1):51. https://doi.org/ 10.18637/jss.v067.i01

Beatty, R., \&Heckman, C. (1981). Survey of urban tree programs in the United States. Urban Ecology 5(2):81-102. https://doi.org/10.1016/03044009(81)90002-4
Bijoor, N.S., McCarthy, H.R., Zhang, D., \& Pataki, D.E. (2012). Water sources of urban trees in the Los Angeles metropolitan area. Urban Ecosystems 15(1):195-214. https://doi.org/10.1007/ s11252-011-0196-1

Bolker, B.M., Brooks, M.E., Clark, C.J, Geange, S.W., Poulsen, J.R., Stevens, M.H.H., \& White, J.S.S. (2009). Generalized linear mixed models: a practical guide for ecology and evolution. Trends in Ecology \& Evolution 24(3):127-135. https://doi.org/10.1016/j.tree.2008.10.008

Close, R.E., Nguyen, P.V., \& Kielbaso, J.J. (1996). Urban vs. natural sugar maple growth: I. stress synmptoms and phenology in relation to site characteristics. Arboriculture \& Urban Forestry 22(3):144-150.

Conway, T.M., \& Urbani, L. (2007). Variations in municipal urban forestry policies: A case study of Toronto, Canada. Urban Forestry \& Urban Greening 6(3):181-192. https://doi. org/10.1016/j.ufug.2007.07.003

De la Barrera, F., Reyes-Paecke, S., \& Banzhaf, E. (2016). Indicators for green spaces in contrasting urban settings. Ecological Indicators 62:212-219. https://doi.org/10.1016/j.ecolind.2015.10.027

Dirección Meteorológica de Chile (2016) No Title. Retrieved from http://www.meteochile.cl Accessed: 5 October 2018.

Di Rienzo, J.A., Casanoves, F., Balzarini, M.G., Gonzalez, L., Tablada, M., \& Robledo, C.W. (2014). 
'InfoStat', Grupo Infoestat, FCA, Universidad Nacional de Córdoba, Argentina. Retrieved from http://www.infostat.com.ar.

Dray, S., \& Dufour, A.B. (2007). The ade4 Package: implementing the duality diagram for ecologists. Journal of Statistical Software 22(4):1-20. https://doi.org/ 10.18637/jss.v022.i04

Escobedo, F.J., Nowak, D.J., Wagner, J.E., De la Maza, C.L., Rodríguez, M., Crane, D.E., \& Hernández, J. (2006). The socioeconomics and management of Santiago de Chile's public urban forests. $U r$ ban Forestry \& Urban Greening 4(3-4):105-114. https://doi.org/10.1016/j.ufug.2005.12.002

Figueroa, J.A., Castro, S.A., Reyes, M., \& Teillier, S. (2018). Urban park area and age determine the richness of native and exotic plants in parks of a Latin American city: Santiago as a case study. Urban Ecosystems 21:645-655. https:// doi.org/10.1007/s11252-018-0743-0

Gabriel, K.R. (1971). The biplot-graphical display of matrices with applications to principal components analysis. Biometrika 58(3):453-467. https://doi.org/10.2307/2334381

Gidlow, C., Ellis, N. \& Bostock, S. (2012) Development of the neighbourhood green space tool (NGST). Landscape and Urban Planning 106(4):347-358. https://doi.org/10.1016/j.landurbplan.2012.04.007

Gillner, S., Vogt, J., Tharang, A., Dettmann, S., \& Roloff, A. (2015). Role of street trees in mitigating effects of heat and drought at highly sealed urban sites. Landscape and Urban Planning143:33-42. https://doi.org/10.1016/j.landurbplan.2015.06.005

Gilman, E., Black, R., \& Dehgan, B. (1998). Irrigation volume and frequency and tree size affect establishment rate. Journal of Arboriculture 24(1):1-9.

Hernández, H.J., \& Villaseñor, N.R. (2018). Twelveyear change in tree diversity and spatial segregation in the Mediterranean city of Santiago, Chile. Urban Forestry \& Urban Greening 29:10-18. https://doi.org/10.1016/j.ufug.2017.10.017

Horneck, D.A., Sullivan, D.M., Owen, J.S., \& Hart, M. (2011). Soil test interpretation guide. Oregon State University Extension Service EC 1478.

Jack-Scott, E., Piana, M., Troxel, B., Murphy-Dunning, C., \& Ashton, M.S. (2013). Stewardship
Success: How community group dynamics affect urban street tree survival and growth. Arboriculture and Urban Forestry 39(4):189-196.

Ko, Y., Lee, J.H., McPherson, E.G., \& Roman, L.A. (2015). Long-term monitoring of Sacramento shade program trees: Tree survival, growth and energy-saving performance. Landscape and Urban Planning 143:183-191. https://doi. org/10.1016/j.landurbplan.2015.07.017

Koeser, A.K., Gilman, E.F., Paz, M., \& Harchick, C. (2014). Factors influencing urban tree planting program growth and survival in Florida, United States. Urban Forestry \& Urban Greening 13(4):655-661. https://doi.org/10.1016/j.ufug.2014.06.005

Kottek, M., Grieser, J., Beck, C., Rudolf, B., \& Rubel, F. (2006). World map of the KöppenGeiger climate classification updated. Meteorologische Zeitschrift 15(3):259-263. https://doi. org/10.1127/0941-2948/2006/0130

Lu, J.W., Svendsen, E.S., Campbell, L.K., Greenfeld, J., Braden, J., King, K.L., \& Falxa-Raymond, N. (2010). Biological, social, and urban design factors affecting young street tree mortality in New York city. Cities and the Environment 3(1):1-15. https://doi.org/10.15365/cate.3152010

Matteson, K.C., \& Langellotto, G.A. (2010). Determinates of inner city butterfly and bee species richness. Urban Ecosystems 13:333-347. https:// doi.org/10.1007/s11252-010-0122-y

Matthies, S.A., Rüter, S., Schaarschmidt, F., \& Prasse, R. (2017). Determinants of species richness within and across taxonomic groups in urban green spaces. Urban Ecosystems 20:897909. https://doi.org/10.1007/s11252-017-0642-9

Morgenroth, J., Santos, B., \& Cadwallader, B. (2015). Conflicts between landscape trees and lawn maintenance equipment: The first look at an urban epidemic. Urban Forestry \& Urban Greening 14(4):1054 1058. https://doi.org/10.1016/j.ufug.2015.10.002

Mullaney, J., Lucke, T., \& Trueman, S.J. (2015). A review of benefits and challenges in growing street trees in paved urban environments. Landscape and Urban Planning 134:157-166. https:// doi.org/10.1016/j.landurbplan.2014.10.013

Nowak, D.J., Kuroda, M., \& Crane, D.E. (2004). Tree mortality rates and tree population projec- 
tions in Baltimore, Maryland, USA. Urban Forestry \& Urban Greening 2(3):139-147. https:// doi.org/10.1078/1618-8667-00030

Paker, Y., Yom-Tov, Y., Alon-Mozes, T., \& Barnea, A. (2014). The effect of plant richness and urban garden structure on bird species richness, diversity and community structure. Landscape and Urban Planning 122:186-195. https://doi. org/10.1016/j.landurbplan.2013.10.005

Pouyat, R.V., Yesilonis, I.D., Russell-Anelli, J., \& Neerchal, N.K. (2007). Soil chemical and physical properties that differentiate urban landuse and cover types. Soil Science Society of America Journal 71(3):1010-1019. https://doi. org/10.2136/sssaj2006.0164

$\mathrm{R}$ Core Team (2011). $R$ : A language and environment for statistical computing. Foundation for Statistical Computing. Retrieved from https://cran.rproject.org/doc/manuals/r-release/fullrefman. pdf. Accessed 5 October 2018

Reyes-Paecke, S., De la Barrera, F., Dobbs, C., Pavez, C., \& Spotorno, A. (2015). Costos de mantención de las áreas verdes urbanas en Chile. Santiago de Chile: Ministerio de Vivienda y Urbanismo. Retrieved from www.minvu.cl/ opensite_20070411164436.aspx

Roman, L.A., Battles, J.J., \& Mcbride, J.R. (2014). Determinants of establishment survival for residential trees in Sacramento County, CA. Landscape and Urban Planning 129:22-31. https:// doi.org/10.1016/j.landurbplan.2014.05.004

Roman, L.A., Battles, J.J., \& McBride, J.R. (2013). The balance of planting and mortality in a street tree population. Urban Ecosystems 17(2):387404. https://doi.org/10.1007/s11252-013-0320-5
Roman, L.A., \& Scatena, F.N. (2011). Street tree survival rates: Meta-analysis of previous studies and application to a field survey in Philadelphia, PA, USA. Urban Forestry \& Urban Greening 10(4):269-274. https://doi.org/10.1016/j.ufug.2011.05.008

Sadzawka, A., Carrasco, M.A., Grez, R., Mora, M.L., Flores, H., \& Neaman, A. (2006). Métodos de análisis recomendados para los suelos de Chile, revisión 2006. INIA. Santiago de Chile.

Sand, E., Konarska, J., Howe, A.W., AnderssonSköld, Y., Moldan, F., Pleijel, H., \& Uddling, J. (2018). Effects of ground surface permeability on the growth of urban linden trees. Urban Ecosystems 21:691-696. https://doi.org/10.1007/ s11252-018-0750-1

Setala, H.M., Francini, G., Allen, J.A., Hui, N., Jumpponen, A., \& Kotze, D.J. (2016). Vegetation type and age drive changes in soil properties, nitrogen, and carbon sequestration in urban parks under cold climate. Frontiers in Ecology and Evolution 4:93. https://doi.org/10.3389/ fevo.2016.00093

USDA (n.d.) Growth habits codes and definitions. Retrieved from https://plants.usda.gov/growth_ habits_def.html.

Van den Boogaart, K.G., \& Tolosana-Delgado, R. (2013). Analyzing compositional data with $R$. Springer-Verlag, Berlin, Heidelberg.

Vogt, J., Gillner, S., Hofmann, M., Tharang, A., Dettmann, S., Gerstenberg, T., Schmidt, C., Gebauer, H., Van de Riet, K., Berger, U., \& Roloff, A. (2017). Citree: A database supporting tree selection for urban areas in temperate climate. Landscape and Urban Planning 157:14-25. https:// doi.org/10.1016/j.landurbplan.2016.06.005 